\title{
ANALISIS PERKEMBANGAN USAHA SIMPAN PINJAM KOPERASI PEGAWAI
}

\author{
Cesillia Marcella, Nuraini Asriati, F.Y. Khosmas \\ Program Studi Pendidikan IPS FKIP UNTAN Pontianak \\ Email: cesillia97marcella@gmail.com
}

\begin{abstract}
This thesis is entitled "Analysis of the Development of Savings and Loans Business Cooperatives for Civil Servants, Tanjungpura University. The method used is descriptive method. The form of the research is qualitative description. Data collection techniques in this study are: direct communication with data collection tools, interview guides, direct observation with data collection tools, observation sheets, documentary studies with data collection tools, Cooperative data archives. With the results of the study as follows: 1) That the development of the savings and loan business of the Public Servant Cooperative of the University of Tanjungpura Pontianak for the period 2017-2019, has seen an increase in the growth of the remaining operating results from year to year where in 2017 it increased by $19 \%$ and then experienced an increase of 19\%. increase in 2019 by 30\%,. 2) Whereas the efforts made by the management in developing the existing businesses at the Public Servant Cooperative of Tanjungpura University Pontianak, while the efforts made are by developing capital, managerial skills, improving the performance of the management and participation of members. 3) Whereas there are 2 factors that influence the development of the efforts of the Public Servant Cooperative at Tanjungpura University, Pontianak, namely internal factors in the form of factors, namely capital development, managerial skills, management performance and member participation, while external factors are caused by the motivation of the cooperative community, supervision from the cooperative supervisory body. and caused by the system of infrastructure, services, education and counseling.
\end{abstract}

\section{Keyword : Analysis of Savings and Loan Business Development, Tanjungpura University Civil Servant Cooperative.}

\section{PENDAHULUAN}

Kegiatan simpan pinjam koperasi dapat meningkatkan permodalan pada koperasi itu sendiri. Kegiatan simpan pinjam adalah kegiatan untuk menghimpun dan menyatukan dana dari anggota yang bersangkutan. Koperasi Pegawai Negeri (KPN) Universitas Tanjungpura Pontianak adalah salah satu koperasi yang berbadan hukum di lingkungan Universitas Tanjungpura Pontianak, menyelenggarakan usaha simpan pinjam serta usaha lainnya yaitu pertokoan. Pada kegiatan usaha simpan pinjam diperuntukan bagi anggota Koperasi Pegawai Negeri (KPN) Universitas Tanjungpura Pontianak. Usaha simpan pinjam merupakan unit usaha yang memiliki tingkat intensitas yang tinggi, dan dalam pemberian pinjaman perlu adanya suatu peraturan yang tepat terhadap perlakuan akuntansi simpan pinjam. 
Dengan adanya perlakuan akuntansi simpan pinjam tersebut dapat membantu ketua koperasi mengambil suatu keputusan tentang kelayakan pemberian pinjaman kepada anggotanya.

Salah satu koperasi yang termasuk dalam jenis Koperasi Serba Usaha (KSU) adalah Koperasi Pegawai Negeri (KPN) Universitas Tanjungpura Pontianak. Koperasi Pegawai Negeri Universitas Tanjungpura Pontianak, pertama kali didirikan pada tanggal 11 Desember 1973 dan telah terdaftar dalam daftar umum Kantor wilayah Departemen Koperasi dan PKK Propinsi Kalimanta Barat dengan Badan Hukum Nomor. 254/BH/PAD/KWK.14/III/1996.

Dalam Undang-Undang Nomor 25 Tahun 1992 tentang perkoperasiaan dinyatakan bahwa: "Usaha koperasi adalah usaha yang berkaitan langsung dengan kepentingan anggota untuk meningkatkan usaha dan kesejahteraan anggota". Usaha koperasi yang dimaksud dalam UndangUndang tersebut mencerminkan bahwa usaha koperasi merupakan kegiatankegiatan koperasi yang dilaksanakan untuk kepentingan dan kebutuhan anggota dengan tujuan memberikan kontribusi terhadap peningkatan ekonomi dan kesejahteraan anggota koperasi itu sendiri.

Diharapkan perkembangan usaha ini koperasi akan dapat meningkatkan skala usahanya, menigkatkan daya saing terhadap pelaku-pelaku ekonomi lainnya dan meningkatkan akses ke pasar, sehingga koperasi dapat memberikan manfaat yang lebih besar kepada para anggotanya. Memperluas dan memanfaatkan peluang usaha tersebut, berarti koperasi dituntut harus mampu melihat secara kritis dan cermat berbagai keadaan dan kondisi lingkungan kegiatan usaha koperasi, termasuk kecenderungan kebutuhan serta kepentingan masyarakat atau anggota sebagai pengguna jasa koperasi yang dapat dimanfaatkan untuk meningkatkan volume usaha serta pendapatan melalui pelayanan yang sesuai dengan kebutuhan.

Salah satu jenis koperasi yang di kembangkan di dalam masyarakat adalah kpoerasi simpan pinjam atau koperasi kredit. koperasi simpan pinjam sesuai peraturan nomor 9 tahun 1995 pasal 1, bahwa koperasi simpan pinjam adalah koperasi yang kegiatannya hanya usaha simpan pinjam. Keanggotaan koperasi simpan pinjam pada prinsipnya bebas bagi semua orang yang memenuhi untuk menjadi anggota koperasi dan orang-orang dimaksud mempunyai kegiatan usaha atau mempunyai kepentingan ekonomi yang sama, misalnya koperasi simpan pinjam dengan anggota karyawan. Berdasarkan pengertian tersebut koperasi simpan pinjam yang melakukan usaha penyimpanan dan peminjaman uang untuk keperluan para anggotanya dan khusus menyediakan dana bagi anggota yang memerlukan dana dengan bunga yang rendah utuk tujuan produktif dan kesejahteraan. Dalam pelaksanaan kegiatannya, hamper sebagian koperasi sangat bergantung dari modal, oleh karena itu modal sangat mempengaruhi pengembangan usaha.

Begitu juga halnya dengan Koperasi Pegawai Negeri Universitas Tanjungpura Pontianak adalah salah satu koperasi yang memfokuskan pada usaha simpan pinjam. Aktivitas Koperasi Pegawai Negeri Universitas Tanjungpura Pontianak adalah simpan pinjam yaitu dengan memberi keleluasaan bagi para anggota untuk menyimpan dana dalam bentuk tabungan untuk kesejahteraan anggota supaya dapat memanfaatkan pendapatannya dengan sebaik mungkin, dan menyalurkan kredit kepada anggota dalam bentuk pinjaman untuk menambah modal koperasi.

Agar lebih jelas tentang perkembangan Sisa Hasil Usaha di Koperasi Pegawai Negeri Universitas 
Tanjungpura Pontianak, maka penulis akan membandingkan laporan Sisa Hasil Usaha tahun buku 2017-2019. Data keuangan tahun 2019, 2018, dan 2017 adalah sebagai berikut pada tahun 2017 Sisa Hasil Usaha sebesar Rp. 80.670.628,00 mengalami peningkatan di tahun 2018 sebesar Rp. 15.610.151 atau sebesar $19 \%$ sehingga menjadi Rp.96.280.779,00 selanjutnya mengalami peningkatan di tahun 2019 sebesar Rp. 29.273.082 atau sebesar 30\%, sehingga Sisa Hasil Usaha di tahun 2019 menjadi Rp. 125.553.861,00.Untuk meningkatkan kemajuan dan meningkatkan eksistensinya, Koperasi Pegawai Negeri Universitas Tanjungpura Pontianak senantiasa melakukan usaha-usaha dalam mengembangkan usahanya. Pengembangan usahanya tersebut tentunya harus memperhatikan kepentingan dan kebutuhan anggota dengan memberikan pelayananpelayanan yang memuaskan agar anggota termotivasi untuk memanfaatkan jasa-jasa yang disediakan koperasi.

Adapun permasalahan yang timbul berdasarkan latar belakang yang telah penulis kemukakan, maka yang menjadi permasalahan utamanya adalah "Bagaimana Perkembangan Usaha Simpan Pinjam Koperasi Pegawai Negeri Universitas Tanjungpura? Mengingat masalah yang dikemukakan masih brersifat umum, maka perlu adanya pembatasan masalah untuk menghidari terjadinya kesalahan dalam penafsiran. Adapun subsub masalahanya dalam penelitian adalah sebagai berikut:1) Bagaiman perkembangan usaha simpan pinjam Koperasi Pegawai Negeri Universitas Tanjungpura Pontianak periode tahun 2017-2019?, 2) Apa upaya yang dilakukan pengurus dalam mengembangkan usahausaha yang ada pada Koperasi Pegawai Negeri Universitas Tanjungpura Pontianak ?, 3) Faktor apa saja yang mempengaruhi pengembangan usaha-usaha Koperasi
Pegawai Negeri Universitas Tanjungpura Pontianak?. Adapun tujuan yang ingin dicapai dari penelitian ini berdasarkan masalah sub-sub masalah adalah sebagai berikut untuk mengetahui:Perkembangan usaha simpan pinjam Koperasi Pegawai Negeri Universitas Tanjungpura Pontianak periode tahun 2017-2019. Upaya yang dilakukan pengurus dalam mengembangkan usaha pada Koperasi Pegawai Negeri Universitas Tanjungpura Pontianak. Faktor yang mempengaruhi pengembangan usaha pada Koperasi Pegawai Negeri Universitas Tanjungpura Pontianak.

Manfaat penelitian ini dibedakan menjadi dua, yaitu manfaat teoritis dan manfaat praktif. Kedua manfaat tersebut adalah sebagai berikut: manfaat teoritis: Penelitian ini diharapkan dapat menambah wawasan pengetahuan pembaca maupun referensi untuk melakukan penelitian sejenis maupun lanjutan yang berkaitan analisis perkembangan usaha simpan pinjam Koperasi Pegawai Negeri Universitas Tanjungpura Pontianak. Manfaat praktisnya bagi peneliti dapat meningkatkan kemampuan dalam mengaplikasikan teori yang selama ini diperoleh dalam perkuliahan untuk dipraktekkan di lapangan. Bagi Koperasi hasil penelitian ini dapat berguna dalam menentukan kebijakan-kebijakan untuk mengembangkan usaha simpan pinjam Koperasi Pegawai Negeri Universitas Tanjungpura Pontianak demi meningkatkan kesejahteraan anggotanya. Bagi anggota koperasi, Penelitian ini dihrapkan dapat memberikan informasi mengenai usaha yang ditempuh koperasi dalam rangka meningkatkan kesejahteraan anggotanya. Untuk memperjelas batasan masalah yang dibahas dalam penelitian ini perlu ditetapkan fokus penelitian dan operasional konsep dengan penjelasan sebagai berikut: fokus penelitian dalam penelitian ini adalah 
"Perkembangan Usaha Simpan Pinjam Koperasi Pegawai Negeri Universitas Tanjungpura". Dengan aspek sebagai berikut: a) Perkembangan usaha simpan pinjam Koperasi Pegawai Negeri Universitas Tanjungpura Pontianak periode tahun 2017-2019. b) Upaya yang dilakukan pengurus dalam mengembangkan usaha pada Kopersi Pegawai Negeri Universitas Tanjungpura Pontianak. c) Faktor yang mempengaruhi pengembangan usaha pada Kperasi Pegawai Negeri Universitas Tanjungpura Pontianak.

Operasional konsep peneliti dilakukan untuk menghindari kesalahpahaman dan perbedaan yang ada antara peniliti dengan pembaca dalam penafsiran maksud suatu istilah yang digunakan dalam penelitian ini. Maka dari itu perlu dibuat penjelasan atau batasan istilah yang berkaitan dengan penelitian ini. Adapun istilah-istilah yang perlu dijelaskan adalah sebagai berikut: Pengembangan Usaha: Dalam penelitian ini Pengembangan usaha adalah adalah modal, simpanan, pinjaman, anggota, SHU, manajemen, pesaing. Dalam penelitian ini dikur dengan perkembangan SHU dan Neraca dari Tahun 2017-2019. Sehubungan dengan perkembangan usaha, hal ini tergantung pada kemampuan pengusaha dan pengelolanya dalam usahanya setiap hari. Pengembangan usaha merupakan sekumpulan aktifitas yang dilakukan untuk menciptakan sesuatu dengan cara mengembangkan dan mentransformasi berbagai sumber daya menjadi barang atau jasa yang diinginkan konsumen. Pengembangan merupakan proses persiapan analitis tentang peluang pertumbuhan potensial dengan memanfaatkan keahlian, teknologi, kekayaan intelektual dan arahan pihak luar untuk meningkatkan kualitas sebagai upaya yang bertujuan memperluas usaha. Perkembangan usaha adalah suatu bentuk usaha kepada usaha itu sendiri agar dapat berkembang menjadi lebih baik dan agar mencapai pada satu titik atau puncak menuju kesuksesan. Perkembangan dalam usaha dilakukan oleh usaha yang sudah mulai dan terlihat ada kemungkinan untuk lebih maju lagi. Perkembangan adalah wujud kesuksesan dalam berusaha yang dapat dilihat dengan jumlah penjualan yang semakin meningkat, kemampuan pengusaha dalam meraih peluang usaha yang ada dan berinovasi, luasnya pasar yang dikuasai, mampu bersaing, mempunyai akses yang luas terhadap lembaga keuangan sehingga dapat meningkatkan pembiayaan usaha. Perkembangan merupakan usaha yang terencana dari organisasi untuk meningkatkan pengetahuan, keterampilan, dan kemampuan pegawai. Pengembangan lebih ditekankan pada peningkatan pengetahuan untuk melakukan pekerjaan pada masa yang akan mendatang, yang dilakukan melalui pendekatan yang teintergrasi dengan kagiatan lain untuk mengubah perilaku kerja.

Dari beberapa pengertian diatas dapat disimpulkan bahwa pengembangan adalah segala sesuatu yang dilaksanakan untuk memperbaiki pelaksanaan pekerjaan atau suatu usaha yang sekarang maupun yang akan mendatang memberi informasi, pengarahan, pengaturan, dan pedoman dalam pengembangan usaha yang ada di Koperasi Pegawai Negeri Universitas Tanjungpura Pontianak

Usaha Simpan Pinjam: Yaitu adalah simpanan atau tabungan anggota KPN Untan Pontianak. Simpanan terdiri dari 3 macam yaitu Simpanan Pokok (SP) Rp.1000,00 perorang dibayar empat kali, Simpanan Wajib (SW) Rp. 200,00 per orang perbulan dan Simpanan Sukarela (SS) Rp. 200,00 per orang perbulan.Koperasi Pegawai Negeri (KPN) Untan Pontianak: Koperasi secara umum diartikan sebagai suatu bentuk usaha 
bersama khususnya dalam bidang ekonomi yang beranggotakan orang-orang atau badan hukum yang berkerja sama secara sukarela dan berdasarkan atas azas keluargaan. Koperasi Pegawai Negeri (KPN) Untan Pontianak adalah Koperasi yang yang beranggotakan Dosen dan karyawan yang berkerja di Universitas Tanjungpura Pontianak serta berdomisili di kota Pontianak beralamatkan Jl. Daya Nasional, Bansir Laut, Kec. Pontianak Tenggara, Kota Pontianak, Kalimantan Barat 78124.

\section{METODE PENELITIAN}

Penelitian yaang dilakukan peneliti berkaitan dengan perkembangan usaha simpan pinjam di Koperasi Pegawai Negeri Untan Pontianak, dimana metode penelitian yang digunakan adalah metode kualitatif deskripsi, yang artinya penelitian ini dilakukan atau disampaikan secara kualitatif, serta menggunakan instrumen penelitian berupa lembar observasi, wawancara serta dokumentasi, untuk nantikan akan di narasikan menjawab pertanyaan penelitian berkaitan dengan perkembangan usaha simpan pinjam di Koperasi Pegawai Negeri Universitas Tanjungpura. Adapun analisis data yang dilakukan oleh peneliti dengan reduksi data maksudnya adalah peneliti memilih datadata yang akan diproses untuk menjawab penelitian, selanjutnya analisis data dengan display data, maksudnya adalah menyusun data yang relevan dengan penelitian sehingga menjadi informasi yang dapat disimpulkan. Selanjutnya analisis data dengan penarikan serta verifikasi data penelitian, maksud yaitu untuk menyimpulan serta menganalisis data yang ada.

\section{HASIL DAN PEMBAHASAN Hasil Penelitian}

Berikut ini adalah hasil penelitian: 1) Perkembangan usaha simpan pinjam Koperasi Pegawai Negeri Universitas Tanjungpura Pontianak periode tahun 2017-2019. Berdasarkan hasil observasi yang dilakukan peneliti berkaitan dengan sub masalah perkembangan usaha simpan pinjam Koperasi Pegawai Negeri Universitas Tanjungpura Pontianak periode tahun 2017-2019, dari hasil laporan keuangan Koperasi Pegawai Negeri Universitas Tanjungpura Pontianak periode tahun 2017-2019, terlihat koperasi mengalami perkembangan Sisa Hasil Usaha di Koperasi Pegawai Negeri Universitas Tanjungpura Pontianak, maka penulis akan membandingkan laporan Sisa Hasil Usaha tahun buku 2017-2019. Berdasarkan tabel diatas terlihat perkembangan sisa hasil usaha dari tahun ke tahun dimana pada tahun 2017 Sisa Hasil Usaha sebesar Rp. 80.670.628,00 mengalami peningkatan di tahun 2018 sebesar Rp. 15.610.151 atau sebesar $19 \%$ sehingga menjadi Rp.96.280.779,00 selanjutnya mengalami peningkatan di tahun 2019 sebesar Rp. 29.273.082 atau sebesar 30\%, sehingga Sisa Hasil Usaha di tahun 2019 menjadi Rp. 125.553.861,00.

Untuk meningkatkan kemajuan dan meningkatkan eksistensinya, Koperasi Pegawai Negeri Universitas Tanjungpura Pontianak senantiasa melakukan usahausaha dalam mengembangkan usahanya. Pengembangan usahanya tersebut tentunya harus memperhatikan kepentingan dan kebutuhan anggota dengan memberikan pelayanan-pelayanan yang memuaskan agar anggota termotivasi untuk memanfaatkan jasa-jasa yang disediakan koperasi. Untuk memperkuat hasil observasi yang dilakukan peneliti, peneliti melakukan wawancara dengan informan pengurus Koperasi KPN Untan Pontianak berkaitan dengan perkembangan usaha simpan pinjam Koperasi Pegawai Negeri 
Universitas Tanjungpura Pontianak periode tahun 2017-2019. Adapun hasil wawancara sebagai berikut:

Dari hasil wawancara berkaitan dengan dengan perkembangan usaha simpan pinjam Koperasi Pegawai Negeri Universitas Tanjungpura Pontianak periode tahun 2017-2019, tiap tahun mengalami perkembangan usaha simpan pinjam, hal ini dikarenakan usaha simpan pinjam yang ada di KPN Untan Pontianak ini usaha simpan pinjam dipengaruhi oleh, jumlah anggota dikarenakan koperasi karyawan, jadi jumlah karywan yang menjadi anggota bertambah, sehingga perkembangan usaha simpan pinjam mengalami peningkatan dari tahun ke tahun. 2) Upaya yang dilakukan pengurus dalam mengembangkan usaha-usaha yang ada pada Koperasi Pegawai Negeri Universitas Tanjungpura Pontianak.

Berdasarkan hasil penelitian berkaitan dengan upaya yang dilakukan pengurus dalam mengembangkan usaha-usaha yang ada pada Koperasi Pegawai Negeri Universitas Tanjungpura Pontianak, yaitu dengan melakukan langkah-langkah sebagai berikut: Dari hasil penelitian upaya yang dilakukan pengurus Koperasi Pegawai Negeri Universitas Tanjungpura Pontianak dalam mengembangkan usaha-usaha yaitu dengan perkembangan modal, dimaan perkembangan moda; bergantung dengan peran aktif pengurus serta anggotanya Koperasi Pegawai Negeri Universitas Tanjungpura Pontianak, berdasarkan hasil penelitian pengurus serta anggotanya Koperasi Pegawai Negeri Universitas Tanjungpura Pontianak, termasuk aktif dalam mengupayakan perkembangan modal karena dalam pengembangan modal pengurus akan berfikir mengenai perolehan modal untuk membiayai kegiatan usahanya. Perkembangan modal dipengaruhi oleh semakin bertambahnya anggota koperasi tahun ke tahun. Keterampilan Manajerial:
Selanjutnya hasil penelitian berkaitan dengan upaya yang dilakukan pengurus dalam mengembangkan usaha-usaha yang ada pada Koperasi Pegawai Negeri Universitas Tanjungpura Pontianak, dimana pengurus mengarahkan inovasiinovasi yang baru, serta mempunyai keterampilan dalam mengelola usaha yang ada di Koperasi. Kinerja Pengurus: Upaya yang dilakukan pengurus dalam mengembangkan usaha koperasi yaitu dengan meningkatkan kinerja pengurus karena dengan kinerja yang baik pengurus bisa mengelola usaha koperasi secara maksimal Partisipasi Anggota: Salah satu upaya yang dilakukan oleh pengurus koperasi Koperasi Pegawai Negeri Universitas Tanjungpura Pontianak, yaitu dengan adanya partisipasi anggota pengurus merasakan dampak pada perkembangan usaha-usaha yang di koperasi.

Untuk memperkuat hasil observasi yang dilakukan peneliti, peneliti melakukan wawancara dengan informan pengurus Koperasi KPN Untan Pontianak berkaitan dengan upaya yang dilakukan pengurus dalam mengembangkan usaha-usaha yang ada pada Koperasi Pegawai Negeri Universitas Tanjungpura Pontianak. Adapun hasil wawancara sebagai berikut:Dari hasil wawancara dengan pengurus koperasi KPN Untan Pontianak, dalam hal upaya yang dilakukan dalam mengembangkan usaha-usaha yang ada di Koperasi Pegawai Negeri Universitas Tanjungpura Pontianak, dengan melalui upaya perkembangan modal dengan cara pengaktifan usaha-usaha yang ada di koperasi, seperti usaha simpan pinjam yang ada di KPN Untan Pontianak, selanjutnya upaya yang dilakukan dengan meningkatkan keterampilan manajerial, yaitu dengan begitu akan adanya inovasiinovasi yang dapat meningkatkan usaha simpan pinjam koperasi, upaya yang 
selanjutnya dilakukan yaitu dengan kinerja pengurus, artinya pengurus mampu didalam mengelola unit simpan pinjam yang di KPN Untan Pontianak, serta upaya selanjutnya yang dilakukan oleh koperasi dengan meningkatkan partisipasi anggota koperasi dalam menggunakan usaha-usaha yang ada di dalam koperasi.3) Faktor apa saja yang mempengaruhi pengembangan usaha-usaha Koperasi Pegawai Negeri Universitas Tanjungpura Pontianak. Berdasrkan hasil observasi yang dilakukan peneliti berkaitan dengan faktor yang mempengaruhi pengembangan usaha-usaha koperasi, terdapat 2 faktor yaitu faktor internal yang berasal dari permasalahan dalam Koperasi Pegawai Negeri Universitas Tanjungpura Pontianak, seperti perkembangan modal, ketrampilan manajerial, kinerja pengurus, dan partisipasi anggota, sedangkan faktor eksternal yang berasal dari luar koperasi yang mempengaruhi pengembangan usahausaha Koperasi Pegawai Negeri Universitas Tanjungpura Pontianak, yaitu motivasi masyarakat berkoperasi, pengawasan dari badan pengawas koperasi, dan sistem prasarana, pelayanan, pendidikan dan penyuluhan.

Untuk memperkuat hasil observasi yang dilakukan peneliti, peneliti melakukan wawancara dengan informan pengurus Koperasi KPN Untan Pontianak berkaitan dengan Faktor apa saja yang mempengaruhi pengembangan usaha-usaha Koperasi Pegawai Negeri Universitas Tanjungpura Pontianak. Adapun hasil wawancara sebagai berikut: Dari hasil wawancara terdapat 2 faktor yang mempengaruhi pengembangan usha-usaha koperasi, yaitu faktor internal seperti perkembangan modal, ketrampilan manajerial, kinerja pengurus, dan partisipasi anggota, sedangkan faktor ekternal yang mempengaruhi pengembangan usaha-usaha Koperasi Pegawai Negeri Universitas Tanjungpura Pontianak, yaitu berupa motivasi masyarakat berkoperasi, pengawasan dari badan pengawas koperasi, dan sistem prasarana, pelayanan, pendidikan dan penyuluhan.

\section{Pembahasan Penelitian}

Perkembangan usaha simpan pinjam Koperasi Pegawai Negeri Universitas Tanjungpura Pontianak periode tahun 2017-2019. Berdasarkan hasil penelitian yang dilakukan peneliti berkaitam dengan perkembangan usaha simpan pinjam Koperasi Pegawai Negeri Universitas Tanjungpura Pontianak periode tahun 2017-2019, yaitu dimana usaha simpan pinjam Koperasi Pegawai Negeri Universitas Tanjungpura Pontianak periode tahun 2017-2019, mengalami perkembangan hal ini dapat dilihat dari laporan SHU dimana perkembangan sisa hasil usaha dari tahun ke tahun dimana pada tahun 2017 Sisa Hasil Usaha sebesar Rp. 80.670.628,00 mengalami peningkatan di tahun 2018 sebesar Rp. 15.610.151 atau sebesar $19 \%$ sehingga menjadi Rp.96.280.779,00 selanjutnya mengalami peningkatan di tahun 2019 sebesar Rp. 29.273.082 atau sebesar 30\%, sehingga Sisa Hasil Usaha di tahun 2019 menjadi Rp. 125.553.861.Hal ini sejalan dengan pendapatnya menurut Afifah dalam Putri dkk (2015:45) pengembangan usaha merupakan sekumpulan aktifitas yang dilakukan untuk menciptakan sesuatu dengan cara mengembangkan dan mentransformasi berbagai sumber daya menjadi barang atau jasa yang diinginkan konsumen. Pengembangan merupakan proses persiapan analitis tentang peluang pertumbuhan potensial dengan memanfaatkan keahlian, teknologi, kekayaan intelektual dan arahan pihak luar untuk meningkatkan kualitas sebagai upaya yang bertujuan memperluas usaha.

Upaya yang dilakukan pengurus dalam mengembangkan usaha-usaha yang ada 
pada Koperasi Pegawai Negeri Universitas Tanjungpura Pontianak. Berdasarkan hasil penelitian yang dilakukan peneliti berkaitan dengan upaya yang dilakukan pengurus dalam mengembangkan usaha-usaha yang ada pada Koperasi Pegawai Negeri Universitas Tanjungpura Pontianak yaitu dengan cara melakukan pengembangan modal usaha sebagai upaya yang dilakukan pengurus selain itu upaya yang dilakukan pengurus yaitu dengan meningkatkan kinerja manajerial hal ini tentunya dilakukan untuk meningkatkan kemampuan pengurus koperasi dalam mengembangkan usaha koperasi dengan keterapilan yang dimiliki oleh pengurus, secara langsung akan memberikan dampak pada kemapuan dalam mengelola usaha yang ada di koperasi, selanjutnya upaya yang dilakukan oleh pengurus dalam mengembangkan usaha-usaha yang ada pada Koperasi Pegawai Negeri Universitas Tanjungpura Pontianak, yaitu dengan meningkatkan kinerja pengurus, peningkatan pada kinerja pengurus akan memberikan pengaruh pada peningkatan usaha-usaha yang ada pada Koperasi Pegawai Negeri Universitas Tanjungpura Pontianak, peningkatan kinerja pengurus yang dimaksud dalam penelitian ini dengan meningkatkan kualitas berkerja dalam memberikan pelayanan prima kepada anggota koperasi, serta upaya yang dilakukan pengurus untuk mengembangkan usaha-usaha dalam koperasi yaitu dengan partispasi anggota koperasi, dengan berperan aktifnya anggota koperasi akan memberikan masukanmasukan kepada pengurus koperasi untuk lebih meningkatkan pendapatan koperasi.

Faktor apa saja yang mempengaruhi pengembangan usaha-usaha Koperasi Pegawai Negeri Universitas Tanjungpura Pontianak. Berdasarkan hasil penelitian berkaitan dengan faktor apa saja yang mempengaruhi pengembangan usaha-usaha Koperasi Pegawai Negeri Universitas
Tanjungpura Pontianak, dari hasil pnelitian terdapat 2 faktor yang mempengaruhi pengembangan usaha-usaha Koperasi Pegawai Negeri Universitas Tanjungpura Pontianak, yaitu faktor internal sebagai berikut: Perkembangan modal, Ketrampilan manajerial, Partisipasi Anggota. Sedangkan faktor eksternal yang mempengaruhi pengembangan usaha-usaha Koperasi Pegawai Negeri Universitas Tanjungpura Pontianak, yaitu: Motivasi masyarakat berkoperasi, Pengawasan dari badan pengawas koperasi, Sistem prasarana, pelayanan, pendidikan dan penyuluhan.

\section{SIMPULAN DAN SARAN Simpulan}

Berdasarkan hasil penelitian Perkembangan Usaha Simpan Pinjam Koperasi Pegawai Negeri Universitas Tanjungpura dapat dikatakan terlaksana dengan baik dan ditinjau dari sub masalah maka dapat disimpulkan. 1)Bahwa Perkembangan usaha simpan pinjam Koperasi Pegawai Negeri Universitas Tanjungpura Pontianak periode tahun 2017-2019, mengalami peningkatan terlihat perkembangan sisa hasil usaha dari tahun ke tahun dimana pada tahun 2017 mengalami peningkatan di tahun 2018 sebesar 19\% selanjutnya mengalami peningkatan di tahun 2019 sebesar sebesar 30\%,. 2) Bahwa upaya yang dilakukan pengurus dalam mengembangkan usaha-usaha yang ada pada Koperasi Pegawai Negeri Universitas Tanjungpura Pontianak, adapun upaya yang dilakukan yaitu dengan pengembangan modal, keterampilan manajerial, peningkatan kinerja pengurus serta partisipasi anggota. 3) Bahwa terdapat 2 faktor yang mempengaruhi pengembangan usaha-usaha Koperasi Pegawai Negeri Universitas Tanjungpura Pontianak, yaitu faktor internal berupa faktor yaitu pengembangan modal, keterampilan 
manajerial, kinerja pengurus dan partisipasi anggota. Sedangkan faktor

\section{Saran}

Hendaknya koperasi memberikan pelayanan kepada anggota ketika berbelanja di koperasi dengan cara pengurus datang tepat waktu, jika anggota belanja di Koperasi pengurus harus melayaninya dengan baik seperti menyapa anggota agar anggota tetap belanja di Koperasi tersebut.

\section{DAFTAR RUJUKAN}

Bungin. 2011. Penelitian Kualitatif. Jakarta: Kencana Predana Media Group. Darmadi. 2014. Metode Penelitian Pendidikan Sosial. Bandung: Alfabeta. Emzir. 2014. Metodologi Penelitian Kualitatif Analisis Data. Cet. 4. Jakarta: Rajawali Pers.
Handoko, T.1991. Dasar-Dasar Manajemen Produksi dan Operasi. Jogja: BPFE.

Hendar. 2010. Manajemen Perusahaan Koperasi. Jakarta: Erlangga.

Jauhari, H. 2013. Terampil Mengarang. Bandung; Nuasansa Cendika

Kaelan. 2012. Metode Penelitian Kualitatif Interdisipliner. Yogyakarta: Paradigma.

Komariah,A 2011. Metode Penelitian Kualitatif. Bandung: Alfabeta.

Lexy J.M,. (2017). Metode Penelitian Kualitatif, cetakan ke-36, Bandung : PT. Remaja Rosdakarya Offset.

Marihot., 2010.Pajak Daerah dan Retribusi Daerah, Raja Grafindo Persada, Jakarta.

Prabu M.A. 2014. Evaluasi Kinerja SDM. Bandung: PT. Refika Aditama.

Undang-Undang Dasar Negara Republik Indonesia Tahun 1945

Undang-Undang Nomor 25 Tahun 1992 Tentang Perkoperasian 